\title{
尋常性天疮瘡によるロ内炎の 2 症例
}

\author{
小池洋二・茂木裕・神戸英明 \\ 筩口礼子・佐鳥茂・松田登
}

\section{Two cases of stomatitis due to pemphigus vulgaris}

\author{
Yoji KoIKe - Yutaka Motegi - Hideaki KanBe
}

Reiko HiguchI - Shigeru SATORI - Noboru MAtSUdA

は じめに

尋常性天泡㾑は慢性の経過をとる難治性の比較的ま礼 な笶患で，しばしば口腔に初発し，数か月から数年にわ たり口腔粘膜だけに限局している場合も起こる。最近， 著者らは口腔粘膜に潰瘍びらん性病変が続き， 口内炎の 一般的処置を行ったにもかかわらず治らなかった症例 を, 再度にわたる病理娭査の結果, 尋常性天疮瘡に由来 する口内炎（尋常性天疮㾑性口内炎）之診断することが できた，その概要を天疮㾑血中抗体価の消長々電顕所見 とを含めて報告する。

$$
\text { 症例 }
$$

\section{症例 1}

患 者: 46歳 女性.

初 診: 昭和 52 年 10 月曰日。

主 訴：舌の痛み。

既往歴：数年前より高血印に罹患し，現在治療中。

家族歴：特記すべき事項はない．

現病歴：昭和52年1月より口腔内にびらん，潰湯がで き，某医で治療を受けていたが症状は軽快しなかった。 8 月某医でヘーーチェット症候群の疑と診断され，当科を 紹介された。

現 症: 括むに両側䫅粘膜, 歯肉, 舌背部に黄白色の 偽膜の付着した不整形の浅い溃瘍びらんが多発し，一部 では上皮は㓦離して鮮紅色を呈し，接触痛とそれに起因 する食慨攝取の障害を訴えていた，偽膜はこすると周辺 の上皮ごと剥れ，出血性の大きなびらん面を現した．舌

Department of Dental and Oral Surgery, School of Medicine, Gunma University (Chief: Prof. Noboru Matsuda)

群馬大学医学部菌科口腔外科(主任：松田 登教授) 受付日：昭和53年12月29日

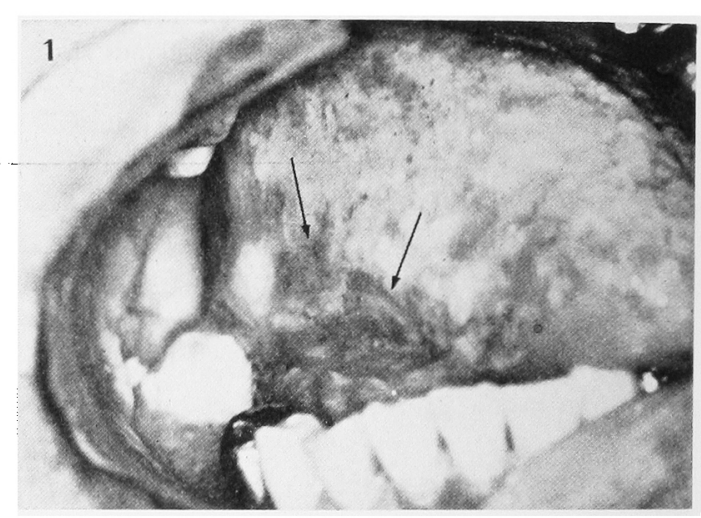

写真 1 矢印は鮮紅色の不整形びらん, 浅い漬場を 指す，舌全体は白濁し，浮腫状を呈する。

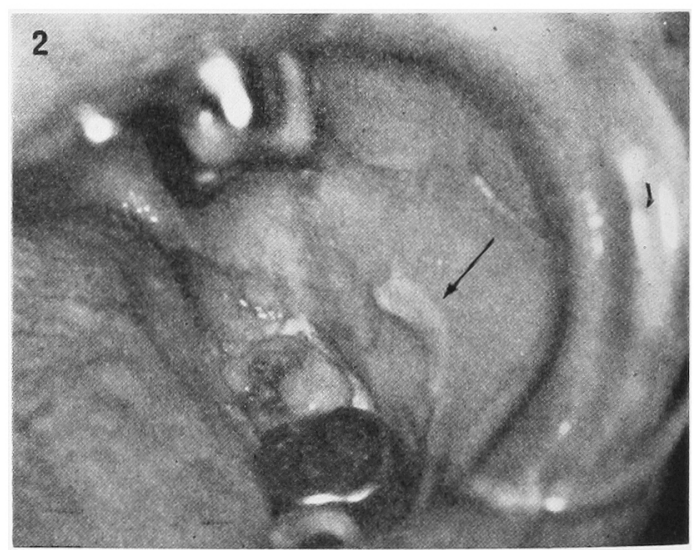

写真 2 矢印は煩粘膜の水疱残渣の付着したびら ん.

は浮尰性で全体的に白濁してみえる（写真 1，2）。全身 の皮局や眼瞼結膜など，口腔粘膜以外の粘膜には異常所 見を訴えていない，血液像をはじめ臨床検查所見に診断 の助けとなる特記事項はなかった。 


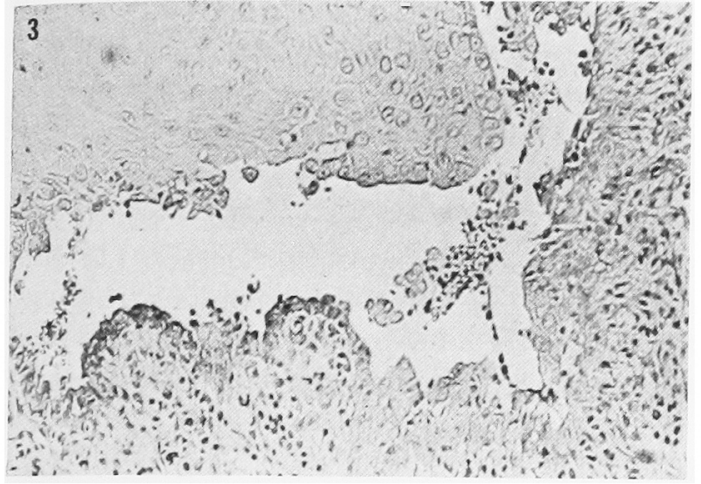

写直 3 頓粘膜の病理組織像 (H. E. 染色, $\times 300)$

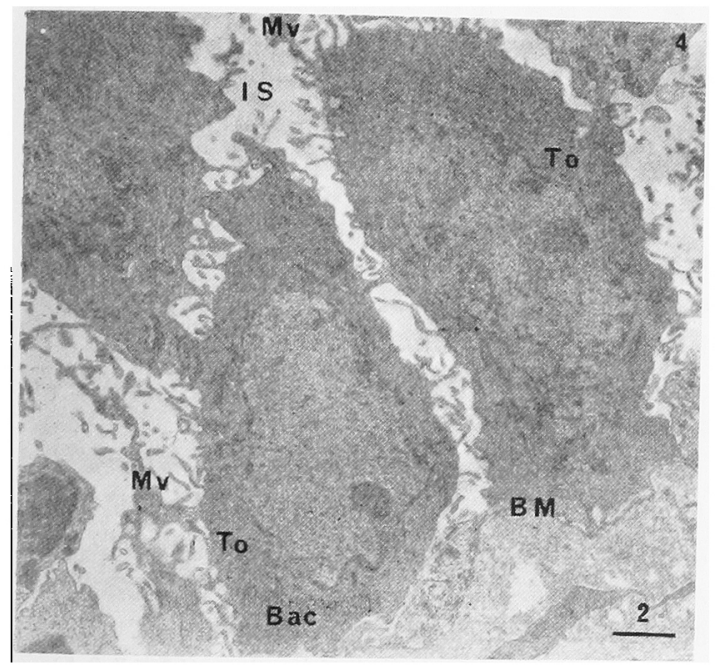

写真 4 水泡直下の梀細胞 $(\times 3,000)$

Mv：德䋐毛, To：張微原線維，Bac：基底細胞， Is：紐胞間隙, BM：基底膜

診 断：天疱瘡性口内炎を疑い，たたちに生険を行っ たが炎性びらん性口内炎ということであった，乙かし天 疮瘡の可能性が強く考えられたので再度の生検を試み， 尋常性天疱㾑の診断を得た。現症よりペーチェット症候 群は否定された。

病理所見：重層上皮, 棘細胞層, 細胞間の水腫と, 棘 細胞層と基底細胞層の間の細胞解離がみられ，裂隙を形 成している。ささらに棘細胞遊離変性が部分的にみられ, リンパ球や好中球が裂吵に少数浸潤している（写真了）.

電䫓所見 : 写真 4 は水疮直下の棘細胞で, 細胞ごとの 連絡が剝れ，デスモゾームの消失が認められる。それに 比べ，媺䄉毛の增生が著明にみられ，張微原線維も少な くなっている．天疮癄の初期変化の状態と考えられる。

导真 5 は水洈側壁の部分で，細胞間の離開がみられ，デ スモゾームは減少し, 微絨毛の増生が認められる，細胞

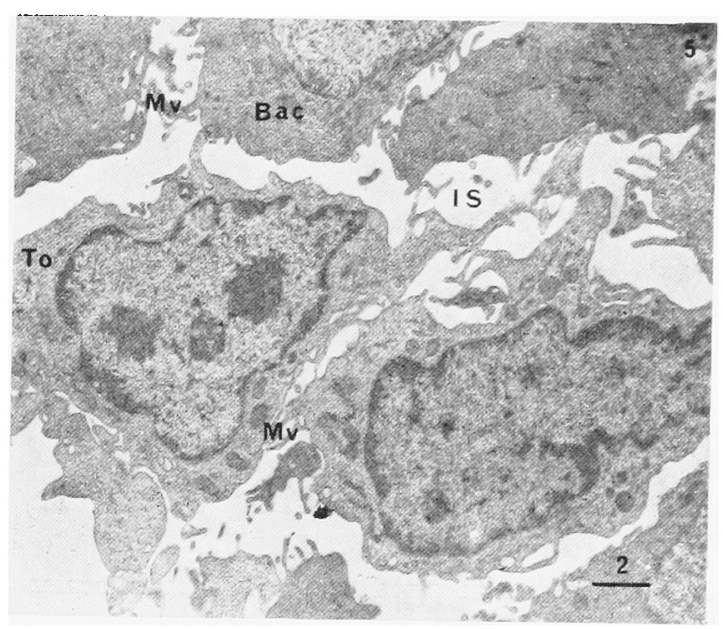

写真 5 水疱側壁部の棘細胞 $(\times 3,000)$

Mv: 微緉毛, Bac: 基底細胞, To: 張德原線踓, IS：細胞間隙

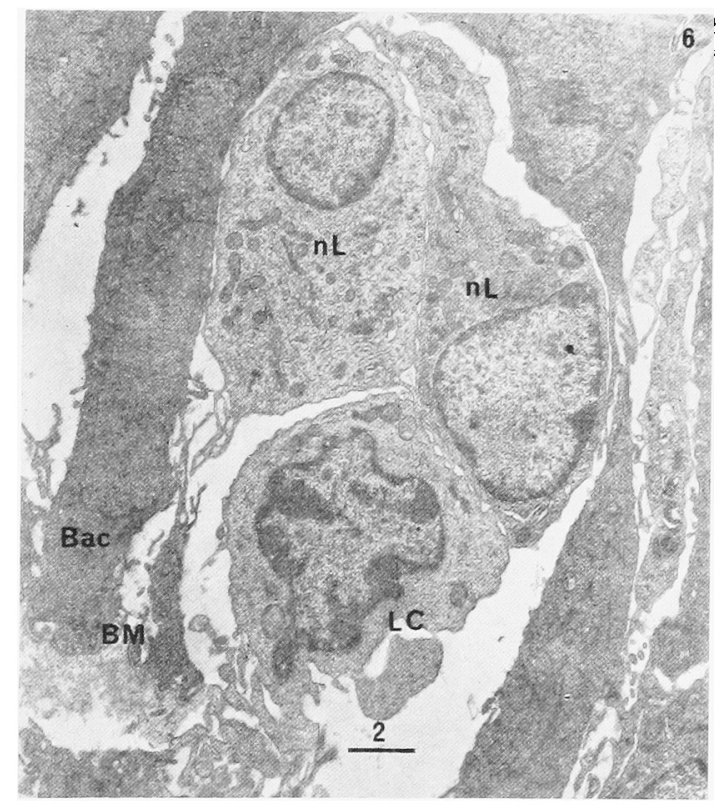

写真 6 上皮細胞間の基底膜部 $(\times 3,000)$ に打 るリンパ球, 好中球の陷入

$\mathrm{nL}$ : 好中球, LC：リンバ球

の変性は少なく, 写真 4 と同様に天疮痏の初期変化と考 它られる。写真 6 は細胞間の基底膜部にリンパ球，好中 球の陥入が認められ，著明な炎症所見を是している部分 である．好中球細胞のミトュンドリア，粗面小胞体など の細胞小器官の発達は良好である. 棘細胞は扁平に王縮 され，細胞間隚の離開も著明である。

処 置: 本学皮膚科に入院加療を依頼 L, I.C. 血中 
表 1 症状と治療扰よび天跑癐抗体価との関係
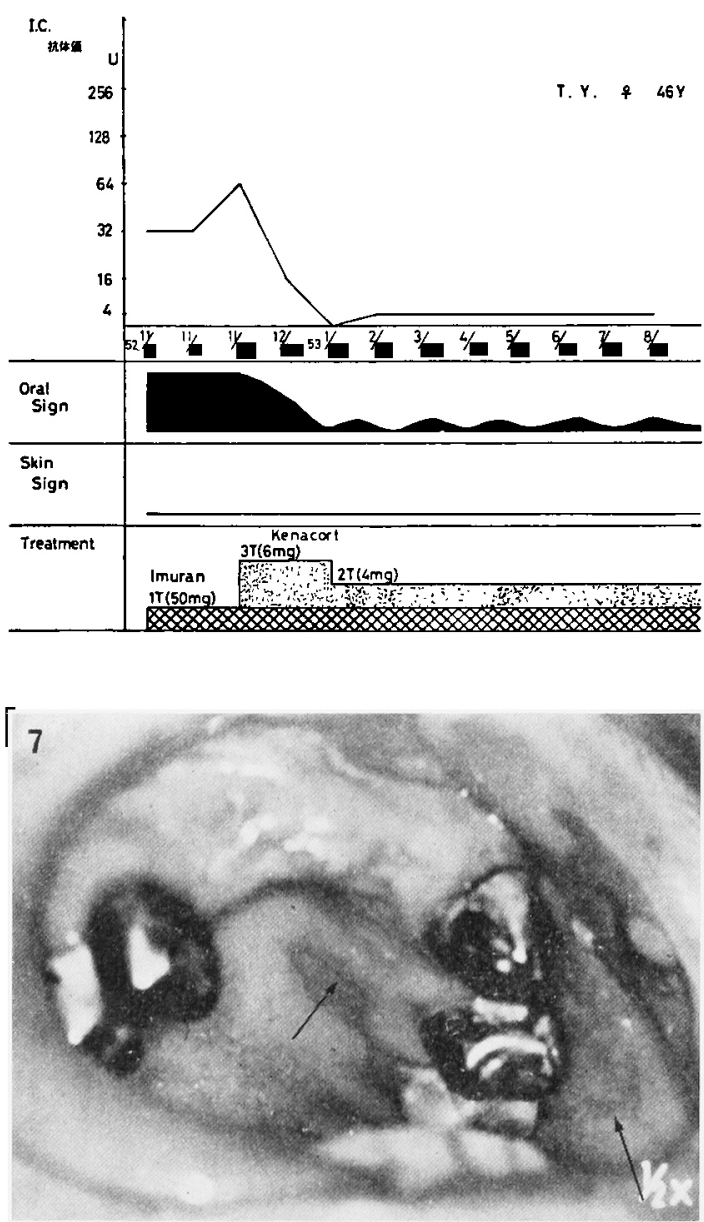

写真 7 矢印は頓粘膜, 口蓋粘膜のびらん, 浅い漬 痬。
抗体洒を測定しつつ症状との関連を観察した，表 1 に示 すごとく，イムラン 1 錠 $(50 \mathrm{mg})$ 単独投与を 16 日行っ たが症状の急激な改善はなかった。ケナコルト3 錠 (6 mg）投与を併用したところ，口腔症状は目にみえて好 転したので57日後にケナコルト 2 錠 (4 mg) に減量し, 維持量として投薬をつつけけている。現在口腔症状は良好 な経過をたどっている，この症例では初回の I.C. 血中 抗体価は $32 U$ と高く, ステロイドの服用による口膑症状 の改善と平行して, I.C. 血中抗体価は $4 \mathrm{U}$ と正常の範 囲内に減少した。な扣腔内清掃とデスパコーワグリセ リンの整布を行っているが，デスパコーワグリセリンの 染布は疼痛をはじめ局所の自覚症状の改善には有効な手 段と思われる。

\section{症例 2}

患 者: 52歳 女性.

初 診: 昭和 52 年 5 月回

主 訴：両側下顎曰歯部雪肉の疼痛.

既往歴：胃炎と下腿骨骨折.

家族歴：特記事項はない。

現病歴：昭和52年 3 月上旬より硬口蓋に違和感がある ため某医を受診し，口内炎と診断されて治療を受け，症 状は軽快した。10日後に発熱ととるに再然し，両側正画 部䨑肉に有痛性の潰瘍があるのに気が付き某医を受診 し，処置を受けたが潰瘍は治痣しなかったので，癌の疑 で当科を紹介された。

現 症：粘膜全体のカタル症状は強く, 両側臼齿部か ら舌縁にかけて大小さまざまの不整形の浅い潰湟びらん が十数個みられ，接触痛は強い，両側煩粘膜から口蓋に かけても大小のびらんとなり，黄白色の破れた水疮の残 渣と思われる上皮がびらん面の辺縁に付着している。舌 下面にも同質のびらん性病変があった（写真 7,8 A). 症例 1 と同様に接触痛による食慨掫取障害があり，また 顎下りンパ節も軽度に董脹し圧痛があった，口腔内の清

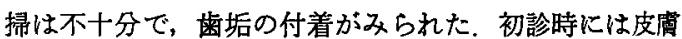

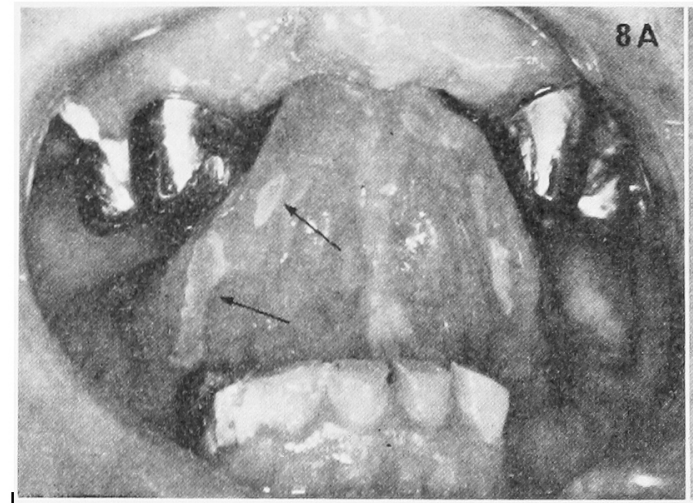

写真 8A 矢印は白苔の付着した舌の小びら

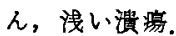

8 B

写真 8B 腹部に生じた小水疱 
をはじぬ他の粘膜には巽常はなく，末血，肝機能などの 血液像には特記すべき所見はなかった。

診 断: 天疱痒病変を疑い，歯肉の溃瘍より組織片を 採取し検查した段階では，炎症性謴湯の診断しか得られ なかった，抗生物質，消炎剂を投与したが効果はなく， 口腔症状は增悪し微熱, 全身異和感も增大してきた。再 度生娭を行ったところ, 尋常性天疮瘡の所見が得られ た. 初回の組織片採取 10 数日後に, 写真 $8 \mathrm{~B}$ のごとく 腹部背部に数個の発赤を伴う小水疮が形成されたが，こ の水疮疹は普通尋常性天疮瘡のさい出現する大きな水疮 疹にくらべると遙かに小さかった。

病理所見：表面は重層扁平上皮で被われ，基底細胞々 棘細胞との間に上皮細胞間の結合の消失があり, 水疮内 に結合を失った上皮細胞を認める。.上皮下組織には血管

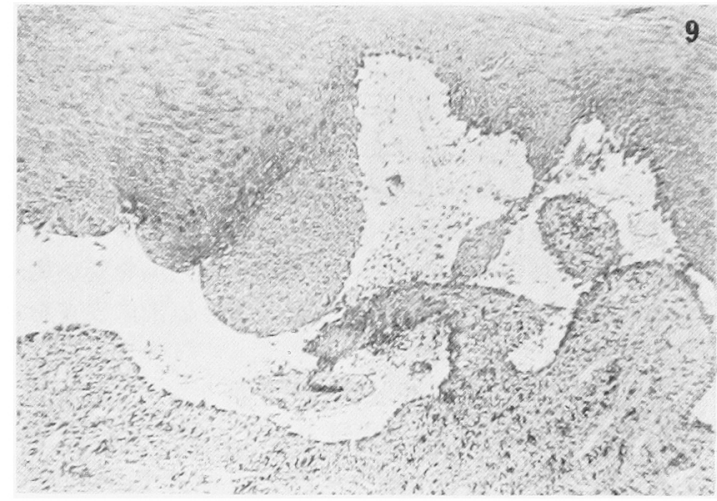

写真 9 頓粘膜の病理組織像 (H.E. 染色, $\times 200)$ の拻張と強、炎症性細胞浸潤がみられる(写真 9 ).

表 2 症状と治潦おょび天疮痽抗体価との関保

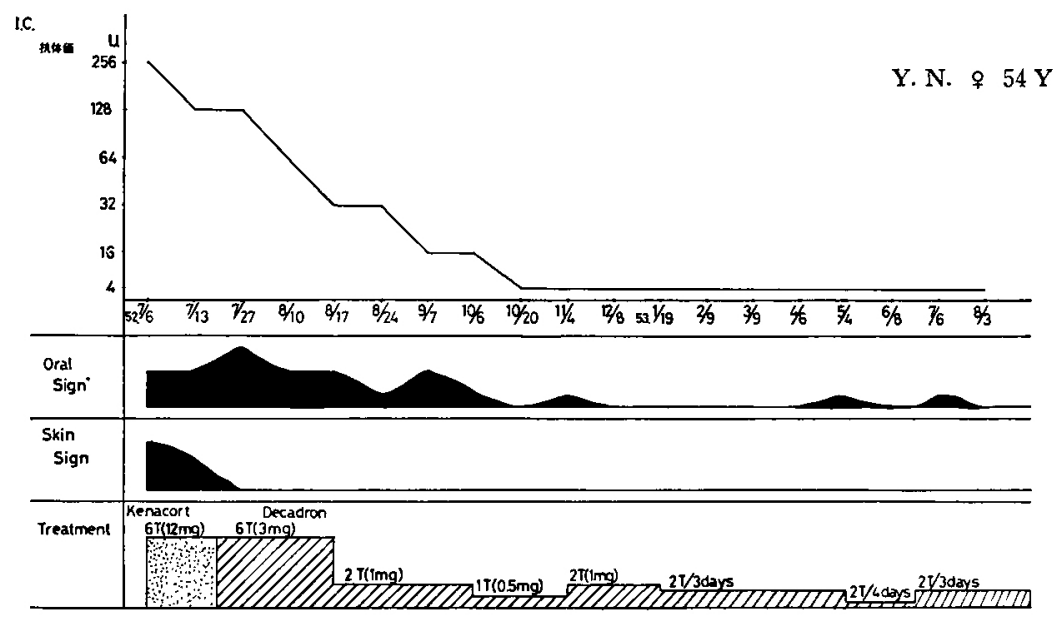

処 置：定型的ではないが，皮尿疹がでていたこと と，治療方法として副督皮質ホルモンの長期投与を行わ ざるを得ないと判断し，皮膚科と協同処置をとることに した，表 2 に局所症状と，治療および I.C. 血中抗体価 との関係を示す。ケナコルト 6 銫（12mg）より内服を 開始したところ，皮眉疹は速かに消失したが口腔内の症 状恃汪とんど変らなかった。 デカドロン 6 錠 (3 mg) の投与に切りかえたところ奏効し，服用 26 日後に $1 \mathrm{mg}$ に減量することができた. I.C. 血中抗体洒の消長である が，初診時に $265 \mathrm{U}$ ときわめて高かったが，副腎皮質製 版投与による口空症状の改善とほぼ平行して $4 \mathrm{U}$ と正常 值の範囲に減少した。 なお局所の清掃, デスパコーワグ リセリンの塗布を励行させた，以後口腔症状の好転をみ たので 2 錠 ( $1 \mathrm{mg}), 1$ 錠 $(0.5 \mathrm{mg})$ の順に減量し, 現 在3 日に 2 銫（1 mg）を維持量とし 経過観察中である が, 溃港やびらん形成は喼められない。

\section{.}

) 
意をはらう、期待した像が得られない場合です，場所を かえて再度試みる必要がある。これを裏付けるかのよう に, 症例 $1 ， 2$ とも再度組織片を採取することによりは じめて天疱㾑の特長ある像を得ることができた，著者ら は少なくとも1か月以上難治性のびらんないし浅い潰瘍 性病変がつづき，その辺縁に黄白色の薄い卵膜様の上皮 残渣が付着した口内炎では，まず第一に天疮瘡を疑い病 理検査, I.C. 血中抗体価の 測定など必要な臨床検査を 行っている.

3）本症例において，診断上有力な手掛りとして患者血 清中に存在する上皮細胞間物質に対する抗体 (I.C. 抗 体）価の上昇をあげた。この I. C. 抗体は Beutner ${ }^{11}$, 12) がはじめての患者血清中に存在することを証明して 以来, 天疮㾑の各病型において認められた。 また螢光抗 体直接法により天疮瘡病変部皮店では, 基底層に $\gamma$ グロ ブリン，兔疫グロブリンなどの存在が報告され13)，これ らの所見は原因不明の本症の病因論に, 自己免度学的機 構の関与が重要な役割を果たしていることを示唆した。

I.C. 抗体価の測定方法は成績の項で述べたように間接

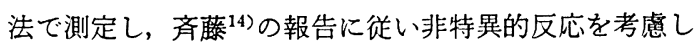
て抗体価 8 倍以上を陽性とした。

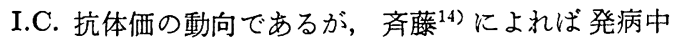
の天疮瘡では全例に I.C. 抗体は証明され，抗体価は症 状と平行して增悪時に高値を軽快時に低值を示し，治撚 状態になると0になる。すでに治癒状態を継続中の症例 では，抗体価は 0 となる。臨床的に無症状となり，抗体 価が低下しても0にならないときは再発しやすい，また 治療を打ち切った後, 抗体価 0 を長期間続けていること が確認されれば予後良好とみなしらる。したがって，本 抗体価の検索には，診断のみならず予後を知るためには なはだ重要な価値があるということである。

症例 1,2 , とも初猃時まで病変は口腔のみに限局 乙，経過からみていまだ初期の段階と考えられたが，す でに I.C. 抗体価関しては, 症例 1 では $32 \mathrm{U}$, 症例 2 では256U と高い陽性值を示し, 再度の病理検査の結果 やっと天疮㾑の確定診断を得た症例であったので，診断 にあたり I.C. 抗体価の測定もまた重要な価值があると いわざるを得ない，そして，コルチコステロイド剤投与 により口腔症状が軽快するにつれて I.C. 抗体価は低下 し，治瘺状態が継続中にいずれも 0 亿を維持している ので，今後症状が激化する可能性は少なく，予後の比較 的良好を示唆する成績と考号られる。啌領域におい て, 天疮㾑性口腔症状と I. C. 抗体価との関係を調べた 報告は，本症例以外には見当たらない，

なお，本症例において治療剤として使用したステロイ ド剂と抗体価との関係であるが，Peck ら ${ }^{15)}$ は影響を及 ぽすと述べている。これに対して，斉藤 ${ }^{44}$ はステロイド が大量投与されているにもかかわらず症状の軽快しなか った時期においても抗体価は低下せず，また軽快したた
めステロイドを減量ないし打ち切っても抗体価の再上昇 が認められなかったことから，抗体価の消長は症状とは 無関係に投与されるステロイドの作用と直結するのでは ないと報告している。

4）尋常性天疮瘡の電顕所見における特異な病変(6)は, 有棘層の萎縮と引きつづき起こるデスモゾームの消失す なわち棘融解と, 張微原線維の退縮すなわち角化異常と である. 棘融解の結果, 有棘細胞間の間隙が異常に広が り大きな空隙を作り水疮が形成される。棘融解の初期に は細胞表面になお䄉毛突起が存在するが, 症状が進むと 細胞の表面は平滑となり，全体として球状を呈するよう になり水疮内に遊離するようになる。橋本ら ${ }^{17}$ は上皮細 胞内では粗面小胞体の発達が悪く, そのために細胞間接 合物質の形成不全をきたし上皮細胞間の接合が失われる と考えている。これらの病変において, Wilgramら ${ }^{18)}$ 張微原線維の退縮が先に起こるといい, Braun-Falco ら 19)はデスモゾームの分離, 崩壊が先に起こると述べてい るがいまだ明らかではない，

症例 1 について写真 4〜6 で示したように, 水疮直 下の棘細胞では細胞ごとの連絡が剝れ, デスモゾームの 消失があり, 張微原線維も少なくなっており, 天疮瘡病 変の特長を備えていた。 そして, 基底膜側の細胞は一部 で良く基底膜に密着し，その部分では細胞変性は認めら れないほど, 臨床経過と同様に電顕像の上からも天疮瘡 の初期変化を示していた。

口腔病変に関する電顕的検討は皮病病変にくらべきわ めて少なく，Hashimoto20)の報告がみられるにすぎな い，著者らの報告が参考になれば幸である。

5）尋常性天疮瘡の処直であるが，山碕ら ${ }^{12}$ の述べてい るように副腎皮質ホルモンは従来試みられていた他のい かなる処置よりも奏効することが多く，予後も著しく好 転した，かつて当科では，デキサメサゾンが著効を示し た 2 症例を報告6)したのであるが，症例 1 ではケナコル ト, 症例 2 ではデカドロンが成績の項で記したように奏 効した。 さらに症例 1 では免疫抑制剂イムランを併用し た。副腎皮質ホルモンもまた免疫抑制作用を持つといら ものの, 本症例では高いI.C. 抗体価を示し, 発症の原 因に強く自己免度学的機構の関与が考えられたので,す でに西本 ${ }^{21)}$, 赤井ら ${ }^{22)}$ が報告しているように免疫抑制剂 と副腎皮質ホルモン製剤との併用療法を行った。この場 合，副腎皮質ホルモンの投与量を減量することができる ので，有益な方法と考えられる。ただ，イムラン単独 投与では奏効しなかった。

$$
\text { む す び }
$$

1） 46 歳と54歳の女性の口腔粘膜に発症した尋常性天疮 瘡による口内炎（噚常性天疮瘡性口内炎）の 2 例を述へ た. 
2) 本症の診断には, 臨床所見と, 初回希望する病理組 織像が得られなくても再度にわたる病理組織検査の必要 性と, I.C. 血中抗体価の測定が重要であることを指摘 した.

3） 口腔粘膜病変の電顕所見は, 皮䖉と同様に棘融解と 角化異常とであり, 尋常性天疮瘕の初期病変を示してい た.

4）本症例の治療にさいして，副腎皮質ホルモン剂およ び免疫抑制剂との併用が奏効した。

本症例の検討にあたり，こ援助こ協力をいたたいた本 学皮薄科紊藤義雄助教授に深謝する。

本要旨は昭和 53 年 9 月, 第 23 回日本口腔外科学会総会 で報告した。

\section{引用 文 献}

1）山碕 順：臨床皮居科全書 Vol 5 水怉症。第 1 版, 金原出版, 東京, 1969，375面。

2）西山茂夫：口腔粘膜疾患診断図説。第 1 版, 金 原出版, 東京, 1970,86頁.

3) 石川梧朗, 他: 口腔病理学 II. 第 3 版, 永末書 店, 京都, 1975, 720頁.

4) Burket, L.W.: Oral medicine. ed 6, Lippincott Co, Philadelphia, 1971, p 78 .

5）獍沢和彦：口腔に限局している尋常性天疮㾴の 1 例。臨皮 23：1155 1967。

6）布施貞夫，他：口腔の天疮㾑性病変について。 口病誌 27: 1721960.

7) 竹田正司, 他：口腔に症状をもった尋常性天疮 瘡 (Pemphigus vulgaris) の 1 例。口外誌 12: 1461966.

8) Shklar, G.: The oral lesions of pemphigus vulgaris. Oral Surg 23: 6291967.

9）本間隆義，他：尋常性天疱痽の 1 例。口科誌 23: 6921974.

10) Zegarelli, E.V., et al.: Intraoral pemphigus vulgaris. OS OM OP 44: 3841977.
11) Beutner, E.H., et al.: Demonstration of skin antibodies in serum of pemphigus vulgaris by indirect immunofluorescent staining. Proc Soc Exper Biol and Md 117: 5051964.

12) Beutner, E.A., et al.: Autoantibodies in pemphigus vulgaris. JAMA 192: 6821965.

13) Jordon, R.E., et al.: Basementzone antibodies in bullous pemphigoid. JAMA 200: 751 1967.

14）斎藤㼁雄：天疮癄および類症の自家抗体特に経 過および予後との閣係。北関東医 21：228 1971.

15) Peck, S.M., et al.: Studies in bullous diseases. New England J Md 279: 9511968.

16）黑住一昌，他：電子顕微鏡による細胞組織図譜 Vol 5 内分泌器皮膚。医学書院, 東京, 1968, 196 頁.

17) Hashimoto, K., et al.: An electron microscopic study on pemphigus vulgaris of the mouth and the skin with special reference to the intercellular cement. J Invest Dermatol 48: 5401967.

18) Wilgram, G.F., et al.: An electron microscopic study of acantholysis and dyskeratosis in pemphigus foliaceus. J Invest Dermatol 43: 2871964.

19) Braun-Falco, O., et al.: Elektronenmikroskopische Untersuchungen zur Dynamik der Acantholyse bei Pemphigus Vulgaris. Arch Klin Exp Dermat 223: 3281965.

20) Hashimoto, K.: Electron microscopy and histochemistory of pemphigus and pemphigoid. OS OM OP 39: 2061972.

21）西本勝太郎，他：イムラン単独使用でコントロ 一ル中の尋常性天疮痏の 1 例。日皮会誌 84 : 臨增 811974 .

22）赤井昭，他：尋常性天狍痽に対するコルチコ ステロイドと6-MP の併用療法. 日皮会誌 84: 4951974. 